\title{
Lectotypification of Sebdenia flabellata (J. Agardh) Parkinson (Gigartinales, Rhodophyta)
}

C. W. Schneider ${ }^{1} \&$ M. J. Wynne ${ }^{2}$

\begin{abstract}
Summary
Schneider, C. W. \& Wynne, M. J.: Lectotypification of Sebdenia flabellata (J. Agardh) Parkinson (Gigartinales, Rhodophyta). - Taxon 40: 471-474. 1991. - ISSN 0040-0262.

Type material of Isymenia flabellata $\mathbf{J}$. Agardh was examined and determined to conform to Sebdenia. The transfer of this taxon to Sebdenia by Parkinson is supported. Sebdenia flabellata (J. Agardh) Parkinson is regarded to be the correct name for a red algal species that includes Sebdenia polydactyla (Børgesen) Balakrishnan. Its taxonomic separation from the superficially similar Halymenia trigona (Clemente) C. Agardh is confirmed.
\end{abstract}

Two discrete taxa are now recognized to have been included in Taylor's (1960, pl. 51, fig. 1, 2) concept of Halymenia agardhii De Toni (Schneider \& Searles, 1975). One of these taxa belongs in Halymenia C. Agardh (Cryptonemiaceae, Gigartinales), and the name $H$. trigona (Clemente) $\mathrm{C}$. Agardh has been applied to that entity (Codomier, 1974). The other taxon belongs in Sebdenia (J. Agardh) Berthold (Sebdeniaceae, Gigartinales), and its correct name is S. flabellata (J. Agardh) Parkinson (1980). Both are widely distributed and have overlapping geographic ranges. The distribution of $H$. trigona includes the eastern and western North Atlantic, the Mediterranean (Taylor, 1960, as H. agardhii pro parte; Codomier, 1974; Gallardo \& al., 1985), and eastern Australia (Millar, 1990). The distribution of $S$. flabellata (including $S$. polydactyla) includes the West Indies, North Carolina, Japan, the Gulf of California, India, South Africa, Indonesia, western and eastern Australia (Børgesen, 1932; Schneider \& Searles, 1991; Norris \& Bucher, 1976; Norris \& Aiken, 1985, Yoshida \& al., 1990; Ballantine \& Norris, 1989; Millar, 1990). These two taxa have been frequently confused because of their morphological resemblance. They share a common morphological expression of a clump of mostly regularly dichotomously branched axes that are terete to subcylindrical and mucilage-filled. Strong evidence supports recognition of two entities, and their reproductive and vegetative differences have been discussed (Schneider \& Searles, 1975; Norris \& Bucher, 1976). The following additional characteristics serve to distinguish these two taxa:

Sebdenia flabellata: thalli coarse, axes reaching a diameter of greater than $2 \mathrm{~cm}$ below the major dichotomies; a regular gradation of axis width down to the ultimate branches is not noticeable; branch tips obtuse; branches lying in one plane; medullary ganglia more numerous and coarse, bearing dark-staining, gland-like cells; tetrasporangia $19-30 \mu \mathrm{m}$ long.

Halymenia trigona: thalli not coarse, axes reaching a width of only $2-6 \mathrm{~mm}$; a regular gradation series in width down to the branch tips, which exhibit tapering and thus are rounded-acute; branching often in more than one plane; medullary ganglia less

\footnotetext{
1 Department of Biology, Trinity College, Hartford, CT 06106, U.S.A.

${ }^{2}$ Herbarium and Department of Biology, University of Michigan, Ann Arbor, MI 41809, U.S.A.
} 
numerous and less coarse; gland-like cells lacking on ganglia; tetrasporangia $15-20 \mu \mathrm{m}$ long.

J. Agardh (1899) described Isymenia flabellata from collections made in the West Indies and Florida. Since the name Halymenia flabellata Schmitz (1895) already existed, De Toni (1905) created the new name $H$. agardhii when he transferred $I$. flabellata to Halymenia. Although he gave no indication of having examined $\mathrm{J}$. Agardh's type of $I$. flabellata, Codomier (1972) stated that $H$. agardhii ought to be placed in the genus Sebdenia; however, Codomier's proposed transfer was invalid because it lacked proper reference to the place of valid publication of the basionym (Art. 33.2 of the ICBN, Greuter \& al., 1988). Codomier (1972) thought that his "Sebdenia agardhil" was very closely related to $S$. polydactyla (Børgesen) Balakrishnan, which was based on material from India. Finally, Parkinson (1980) correctly pointed out that since the epithet flabellata was not occupied in Sebdenia, the name of this species should be $S$. flabellata (J. Agardh) Parkinson.

Contemporary workers have made no mention that they have examined J. Agardh's (1899) original material on which his Isymenia flabellata was based, to determine whether it belongs to Sebdenia or to Halymenia. Through the kindness of Dr. Per Lassen, Curator of the Agardh Herbarium in Lund, we have been able to receive on loan the syntypes of I. flabellata. They comprise nine cards with eight mounted specimens (annotated LD 22284 through 22292). [Card 22290 is a note in J. Agardh's hand referring to specimens 22291 and 22292.] All of the specimens bear the diagnostic gland-like cells on large medullary ganglia, and the axes show flabellate branching in a single plane. Thus, we can state with confidence that all belong to Sebdenia and represent the same taxon. The eight specimens were initially identified as the following:

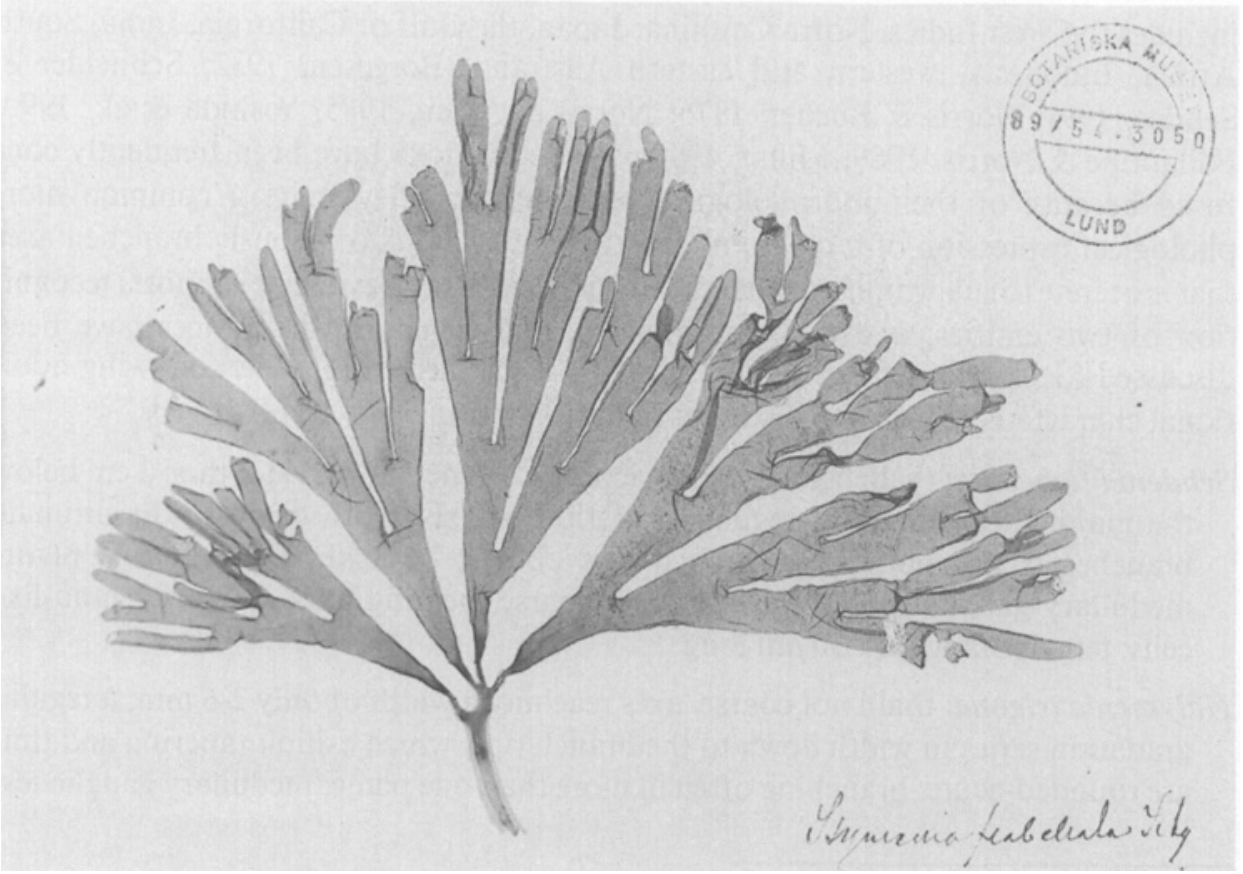

Fig. 1. Lectotype specimen of Isymenia flabellata J. Agardh [i.e., Sebdenia flabellata (J. Agardh) Parkinson], LD 22292. 
LD 22284: Halymenia decipiens J. Agardh, distributed in 1878 as No. 80 in Farlow, \& al's Algae exsiccatae americae borealis. Collected in Key West, by F. W. Hooper. Vegetative young (small) specimens.

LD 22285-87: All Halymenia decipiens, annotated in J. Agardh's hand as I. flabellata. Collected in Indian River (Florida) by Mrs. G. A. Hall. Vegetative, large specimens. LD 22289 (possibly also 22288): Scinaia furcellata var. undulata. Collected in Key West by Mrs. G. A. Hall. Vegetative, large.

LD 22291-92: Specimens cited in Flora guadeloupensis as "Chrysymenia dichotomoflabellata Crouan msc." (back of sheets mention only "Guadeloupe"). Both bear numerous tetrasporangia and are large specimens.

Since no holotype was distinguished by J. Agardh, we hereby designate as lectotype one of the two cards from Guadeloupe, LD 22292 (Fig. 1), since they are the only reproductive specimens (tetrasporangia) among the syntypes of J. Agardh (1899: 62). Furthermore, LD 22292 is a large specimen bearing the typical morphology for the taxon, including inflated axes, swollen nodes, and obtuse apices.

Another question is whether Sebdenia flabellata and S. polydactyla can be differentiated. Tseng \& al. (1980) stated that Hong Kong specimens showed the roundness of the axils of S. polydactyla on the one hand and the blunt-ending, ultimate branches and smaller thallus of $S$. flabellata on the other, and they concluded that these two species did not seem to be distinct.

The following expresses our understanding of the synonymy of these two species discussed in this paper:

Sebdenia flabellata (J. Agardh) Parkinson (1980: 12).

三Isymenia flabellata J. Agardh (1899: 62, 66), non Halymenia flabellata Schmitz (1895: 162).

$\equiv$ Halymenia agardhii De Toni (1905: 1542).

= Halymenia polydactyla Børgesen (1932: 122).

= Sebdenia polydactyla (Børgesen) Balakrishnan (1961: 212).

Halymenia trigona (Clemente) C. Agardh (1822: 211).

$\equiv$ Fucus trigonus Clemente (1807: 318).

$\equiv$ Halarachnion trigonum (Clemente) Kützing (1849: 722).

三 Isymenia trigona (Clemente) J. Agardh (1899: 67).

See Codomier (1974) for other synonyms.

It should be noted that in Codomier's (1974) designation of a "lectotype" of Halymenia trigona, he selected a specimen (Agardh Herb., LD 22312) which was sent from Cadiz by A. Cabrera to C. Agardh. An appropriate lectotype in our opinion would be a specimen of Fucus trigonus Clemente in the Instituto Botanico A. J. Cavanilles, Madrid (MA).

\section{Acknowledgements}

We wish to thank Dr. Per Lassen (Lund) for the loan of Isymenia flabellata J. Agardh.

\section{Literature cited}

Agardh, C. A. 1822. Species algarum..., 1(2). Berling, Lund.

Agardh, J. G. 1899. Analecta algologica. Observationes de specibus algarum minus cognitis earumque dispositione. Cont. 5. Acta Univ. Lund. 35(4). 
Balakrishnan, M. S. 1961. Studies on Indian Cryptonemiales. III. Halymenia C. A. Ag. J. Madras Univ. Sect. B, 31: 183-217.

Ballantine, D. L. \& Norris, J. N. 1989. Notes on the marine algae of Puerto Rico. V. New additions to the flora. Caribbean J. Sci. 25: 1-8.

Børgesen, F. 1932. Some Indian Rhodophyceae, especially from the shores of the Presidency of Bombay. II. Bull. Misc. Inform. 1932: 113-134.

Clemente y Rubio, S. de R. 1807. Ensayo sobre las variedades de la vid comun que vegetan en

Andalucia, con un índice etimológico y tres listas de plantas en que se caracterizan varias especies nuevas. Villapando, Madrid.

Codomier, L. 1972. Sur le développement comparé des spores des Sebdéniacées (Gigartinales) et des Cryptonémiacées (Cryptonémiales). Compt. Rend. Hebd. Séances Acad. Sci. Sér. D, 275: 747-749.

- 1974. Recherches sur la structure et le développement des Halymenia C. Ag. (Rhodophycées, Cryptonémiales) des côtes de France et de la Méditerranée. Vie \& Milieu, Sér. A, Biol. Mar. 24: 1-42.

De Toni, G. 1905. Sylloge algarum omnium hucusque cognitarum, 4(4). Privately published, Padova.

Gallardo, T., Gómez Garreta, A., Ribera, M. A., Alvarez, M. \& Conde, F. 1985. A preliminary checklist of Iberian benthic marine algae. Real Jardín Botánico, Madrid.

Greuter, W., Burdet, H. M., Chaloner, W. G., Demoulin, V., Grolle, R., Hawksworth, D. L., Nicolson, D. H., Silva, P. C., Stafleu, F. A., Voss, E. G. \& McNeill, J. (ed.), 1988. International code of botanical nomenclature, adopted by the Fourteenth International Botanical Congress, Berlin, July-August 1987. Regnum Veg. 118.

Kützing, F. T. 1849. Species algarum.... Brockhaus, Leipzig.

Millar, A. J. K. 1990. Marine red algae of the Coffs Harbour region, northern New South Wales. Austral. Syst. Bot. 3: 293-593.

Norris, J. N. \& Bucher, K. E. 1976. New records of marine algae from the 1974 R/V Dolphin cruise to the Gulf of California. Smithsonian Contr. Bot. 34.

Norris, R. E. \& Aken, M. E. 1985. Marine benthic algae new to South Africa. S. African J. Bot. 51: 55-65.

Parkinson, P. G. 1980. Halymenia... Phycologiae historiae analecta autodidactica, fasciculus primus. The Pettifogging Press, Auckland.

Schmitz, F. 1895. Marine Florideen von Deutsch-Ostafrika. Bot. Jahrb. Syst. 21: 137-177.

Schneider, C. W. \& Searles, R. B. 1975. North Carolina marine algae. IV. Further contributions from the continental shelf, including two new species of Rhodophyta. Nova Hedwigia 26: 83-103.

- 1991. Seaweeds of the southeastern United States: Cape Hatteras to Cape Canaveral. Duke University Press, Durham, NC (in press).

Taylor, W. R. 1960. Marine algae of the eastern tropical and subtropical coasts of the Americas. University of Michigan Press, Ann Arbor.

Tseng, C. K., Chang, C. F., Xia Enzhan \& Xia Bangmei, 1980. Studies on some marine red algae from Hong Kong. Pp. 57-84 in: Morton, B. S. \& Tseng, C. K. (ed.), Proceedings of the First International Marine Biological Workshop: The marine flora and fauna of Hong Kong and Southern China. Volume I: Introduction and taxonomy. Hong Kong University Press, Hong Kong.

Yoshida, T., Nakajima, T. \& Nakata, Y. 1990. Check-list of marine algae of Japan (revised in 1990). Jap. J. Phycol. 38: 269-320. 